\title{
プローブ自転車による自転車歩行者道のバリア調査法*
}

\section{Investigation of Barrier on Bicycle-Pedestrian Track with Probe Bicycle*}

斎藤健治** ・清田 勝***

By Kenji SAITOU** · Masaru KIYOTA***

\section{1.はじめに}

現在の日本における歩行環境や自転車走行環境は, 段差, 劣化した舗装, 狭い幅員, 車優先のすりつけ勾 配や必要以上の排水のための横断勾配などに見られる ように，自動車走行環境に比べ貧弱であるだけでなく， 危険すら感じられる。このような現状にもかかわらず, これからの高齢社会に拀いて, 移動手段として徒歩 (車 いすを含む)，あるいは自転車を選択する高齢者が増加 することは容易に想像されるところである ${ }^{1}$ 。さらに, 環境・健康問題 ${ }^{2)}$, コンパクトシテイなどのまちづくり の観点から, 歩道や自転車歩行者道の整備は, 今後, 車道整備以上に重要課題として捉えられるべき喫緊の 課題といえる.

高齢社会を見据えて，自転車道を整備するに当たつ ては，高齢者がどのように自転車走行するが，あるい は高齢者の走行が段差・公配にどのような影響を受け るが辛調査することにより，整備のための評価や判 断の基準を設定することが可能になる。一方で，自転 車歩行者道を継続的に整備していくためには, 必要に 応じて現状を調査することが重要であり，そのために は，できるだけ人手を必要としない計測技術や IT 技術 を用いた総合的なシステム作りが課題となる。つまり， 労力をできるだけかけず, 迅速に情報を収集し，その 結果や整備結果を管理するために, データベース化し, GIS（地理情報システム）により，バリアフリーマップ やアクセシビリティマップなどの形で情報を公開する ことが必要である。

そこで本研究では, 計測技術の段階であるが, 自転 車歩行者道の状況（バリア）を調査するプローブ自転 車を開発し, 実際の歩道や自転車歩行者道の調査への 適用可能性を探ることが目的である。

* キーワーズ：地域計画, 市街地整備, 測量

** 正員 博士 (体育科学) 佐賀大学理工学部都市工学科

( (840-8502 佐賀市本庄町 1, TEL: 0952-28-8573,

FAX: 0952-28-8190, E-mail: saiken@cc.saga-u.ac.jp)

*** 正䝿 工博 佐賀大学理工学部都市工学科

（示840-8502 佐賀市本庄町 1, TEL : 0952-28-8953,

FAX: 0952-28-8190, E-mail: kiyotam@cc.saga-u.ac.jp)

\section{2. プローブ自転車}

市販の三輪自転車にセンサを装着してプローブ自転 車とした (写真 -1$)$.

装着したセンサは, ハンドルのふれ角を計測する単 回転式のポテンショメー夕 (Copal 社製, JC22E)，段差 や路面凹凸を通過したときに生じる振動加速度を計測 する 2 軸の加速度センサ (Analog Devices 社製, ADXL210), 走行スピードを計測する磁気センサ

(CATEYE 社製, CC-VL100), 歩道の縦断勾配と横断 勾配を計測する 2 軸の加速度センサ (Analog Devices 社 製, ADXL202）および角速度を計測する 2 個のジャイロ センサ（村田製作所社製, ENC-03JA）であった。

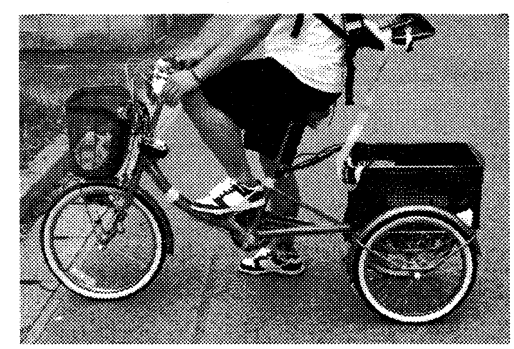

写真 - 1 プローブ自転車

ポテンショメータは, ハンドルステム下のフレーム に装着し，ハンドルの回転にともなうステムの回転を 検出した (写真 - 2). 段差通過時の振動加速度を計測 する加速度センサは，ポテンショメータと同じ位置に，

2 軸の感度方向を鉛直方向と前後方向に合わせて装着 した (写真 -2$)$.

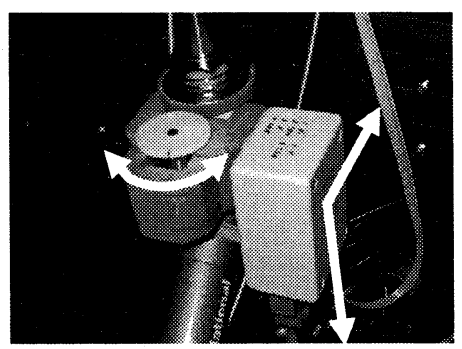

写真 - 2 ハンドルふれ計測用のポテンショメータと振動加 速度計測用の加速度センサのボックス 
縦断と横断両方向の勾配を計測する加速度センサ， および角速度を計測するジャイロセンサは，後部荷台 に装着した，加速度センサの 2 軸の感度方向は前後左 右で，荷台が水平の時に $0 \mathrm{G}$ になるように装着し，ピッ チ角，ロール角を計測する傾斜センサとして用いた。 ジャイロセンサは後部荷台の動的な傾斜変化を検出す るために，ロールとピッチの角速度を計測できるよう に装着した（写真－3）.

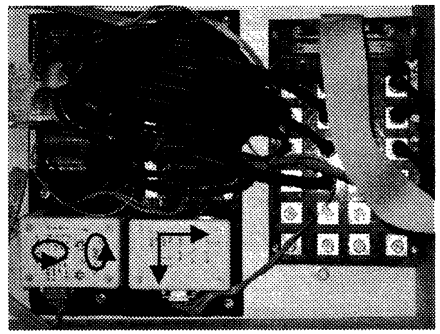

写真 -3 勾配計測用の加速度センサと角速度計測用のジャ イロセンサのボックス

計測した信号は, 長さ 15 秒, 精度 12 bit, 周波数 $500 \mathrm{~Hz}$ でサンプルし，運転手の背中に背負ったノートブック 型パーソナルコンピュータ（東芝社製，Libretto L3）に 取り込んだ。

\section{3. 段差計測}

段差通過時の加速度から段差を推定するために, 走 行スピード，段差高と加速度との関係を調べた。変数 閒の関係を線型モデルで近似し, 段差通過時のスピー ドと加速度から段差高を推定した。

\section{（1）方法}

舗装された実験走行路上に木製の板を重ねた段差を 設置し，その上をプローブ自転車で通過した．段差の 高さは $10,20,30,40$ および $50 \mathrm{~mm}$ の 5 種類で, 同一段 差において 5 回の試技を行った。自転車の走行スピー ドは， 5 回の試技において 8 16 km/h の範囲で 5 段階 のスピードとなるよう主観で走り分けてもらった。 夕 イヤ空気压は $3.5 \mathrm{~kg} / \mathrm{cm}^{2}$ とした $\left(3.0\right.$ および $4.0 \mathrm{~kg} / \mathrm{cm}^{2}$ においても計測を行ったが, 空気压の明確な影響は認 められなかった)。

段差通過時にハンドルステム下で計測した振動加速 度を用いて，段差高を推定するために，次のような線 型モデル（重回帰モデル）をたてた.

$$
y=a_{1} x_{1}+a_{2} x_{2}+b
$$

ここで $y$ は段差高 $(\mathrm{mm}), x_{1}$ は (合成の) 振動加速度 $(\mathrm{G})$, $x_{2}$ は走行スピード $(\mathrm{km} / \mathrm{h}), a_{1}, a_{2}, b$ は定数である.

\section{(2) 結果}

図ー1に 2 軸の加速度センサにより計測した, 上下方 向と前後方向の加速度波形の一例を示す.これは, 高 さ $20 \mathrm{~mm}$ の段差を $14 \sim 15 \mathrm{~km} / \mathrm{h}$ のスピードで通過（上 り下り）したときの加速度波形である. 最初の正のピ ークが, プローブ自転車の前輪の登段時, 2 つ目の負の ピークが降段時である.

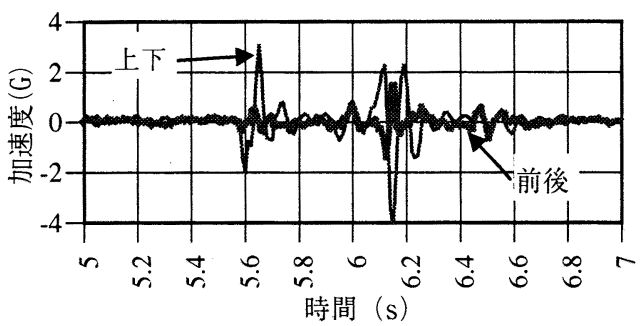

図 - 1 段差通過時の上下, 前後方向加速度の波形例

予備実験の結果，段差通過時に生じる振動加速度は， この 2 軸の成分がほとんどであることが確認され， 3 軸 目の左右方向の加速度は必要ないと判断された.

上記 2 軸の加速度を合成した合成加速度波形のピー ク值を重回帰モデル式（1）の $x_{1}$ とした。ささらに, 段差 通過時の走行スピードを重回㷌モデルの $x_{2}$ とし, 全 25 試技の計測結果から，

$$
y=8.547 x_{1}-0.479 x_{2}-2.068
$$

というモデルが決定された。（2）式を用いることによ り，走行中に計測される振動加速度と走行スピードか ら，段差高が推定できた（図一2）.

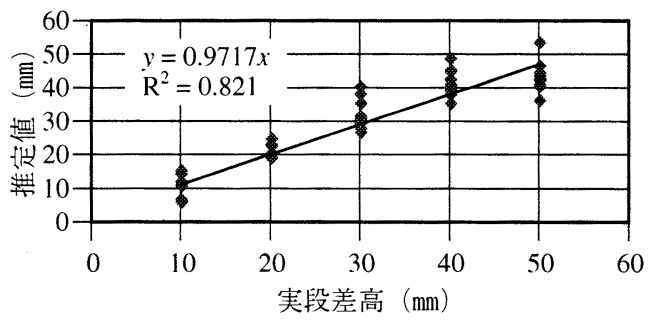

図－2 重回帰モデルによる推定結果

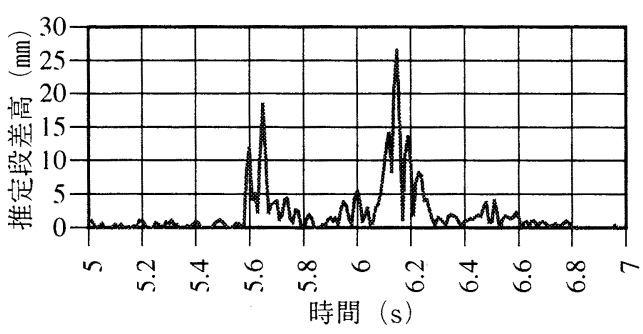

図－3重回帰モデルによる段差推定例 
図－3に，図ー1に示した加速度と走行スピードから， （2）式により求めた推定段差高の時系列波形を示す. 登段時については実際值に近い推定值が得られたが, 降段時は $6 \mathrm{~mm}$ 程度高く推定された。また, 加速度波形 にそのままモデルを当てはめるため, ピーク周辺にゴ 一ス卜様の波形も現れているが, 段差の有無は, 時系 列波形から明確に判断できるといえる。

\section{4. 幅員計測}

スラローム走行時のハンドルふれ角と走行スピード から走行軌跡を求め, その軌跡幅から幅員を推定した。

\section{（1）方法}

実験走行路上に幅員を示す白線を引き，前輪がその 白線に触れるようにスラローム走行を行った。幅員の 条件は，0.5, 0.6, 0.7, 0.8, 0.9, 1, 1.5 および $2 \mathrm{~m} の 8$ 種類 であった. 走行路の幅員を示す線の外側に, $5 \mathrm{~m}$ 間隔で パイロンを設置し，走行の目安とした。

走行軌跡は, 時間 $t$ の関数としてのハンドルの振れ角 $\theta(t)$ と走行スピード $S(t)$ から求められる. 任意の時刻 $t_{\alpha}$ に㧍ける自転車の位置座標（進行方向座標，ふれ方 向座標）は，

$$
\left(\int_{0}^{t_{\alpha}} S(t) \cos \theta(t) d t, \int_{0}^{t_{\alpha}} S(t) \sin \theta(t) d t\right)
$$

$$
\text { となる }{ }^{3)} \text {. }
$$

\section{(2) 結果}

図-4ー6に，幅員 $0.5 \mathrm{~m}, 1 \mathrm{~m}$, 抢よび $2 \mathrm{~m}$ の走行路孛 スラローム走行したときの，ハンドルふれ角と走衍ス ピードから（3）式を用いて求めた走行軌跡を示す。こ こでは軌跡の最大幅をもって幅員とした。図ー4〜6に 示されているように，実際の幅員を再現することはで きなかった。それはここに示していない幅員におい ても同様であり，最大で約 40\%の誤差が生じたケース があった。

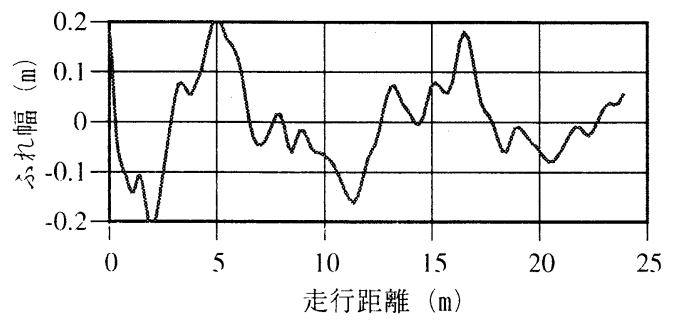

図-4 幅員 0.5 m でのスラローム走行結果

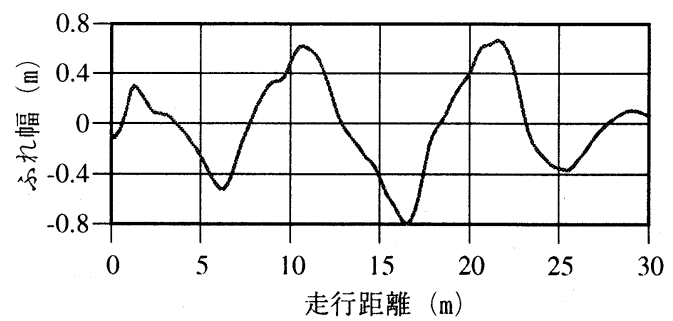

図－5 幅員 1.0 m でのスラローム走行結果

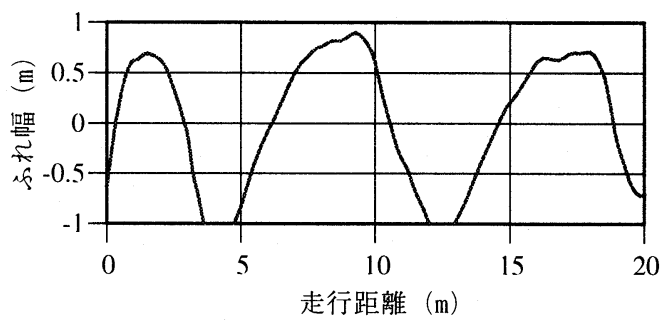

図 - 6 幅員 2.0 m でのスラローム走行結果

\section{5. 勾配計測}

公配推定には，傾斜そのものを計測する手法と，角 速度を計測して積分する手法がある。ここでは, 加速 度センサを傾斜センサとして用い，勾配を計測した。 さらに，勾配変化による自転車体のローリングとピッ チングの角速度を, ジャイロセンサを用いて計測した。 ジャイロセンサは, 走行にともなう直進加速度の影響 がなく, 角速度を積分することで勾配を求めることが できる。

\section{（1）方法}

縦断勾配 6 8\%程度の既設スロープ (陸橋) と波打 ち歩道の実走行を行い, 加速度と角速度の計測を行っ た。加速度センサの出力には, 重力加速度以外に, 直 線加速度, 回転運動にともなう遠心加速度，振動によ る加速度などが含まれるため，これらを除去しなけれ ば，勾配の影響による重力成分を抽出することができ ない，そこで本研究では，カルマンフィルタと平滑化 アルゴリズムにより，振動的な波形から勾配の影響に よるトレンドの抽出を行った。得られた加速度のトレ ンドから勾配 $\mathrm{grad}(\%)$ を求めた。

$\operatorname{grad}=\tan \left(\sin ^{-1}(\right.$ accel $\left.)\right) \times 100$

ジャイロセンサにより計測した角速度波形にも振動 の影響が含まれており, 同様に平滑化によりトレンド を求めた。 


\section{(2) 結果}

図－７にスロープを登坂したときの加速度波形と平 滑化により求めたトレンド波形を示す。デー夕収集の ための走行開始直後に走行開始にともなう加速度の影 響を受けて，推定值に誤差を生じた。走行スピードが 安定した後は，実勾配に近い推定值を得ることができ た．図-8に，同一の場所で計測した角速度波形（ピッ チ）と平滑化により求めたトレンド波形を示す。ほと んど勾配変化のない場所であるため, ピッチ，ロール ともに角速度は計測されないはずであるが，振動の影 響により，偽の角速度波形が認められた。しかし，同 様にトレンド推定することより，振動の影響を除去す

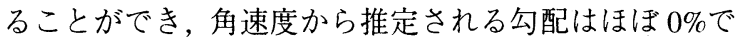
あった。

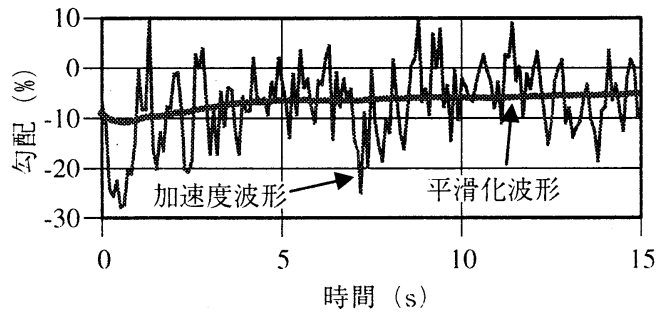

図ー7 スロープを登坂したときの加速度波形と平滑化波形

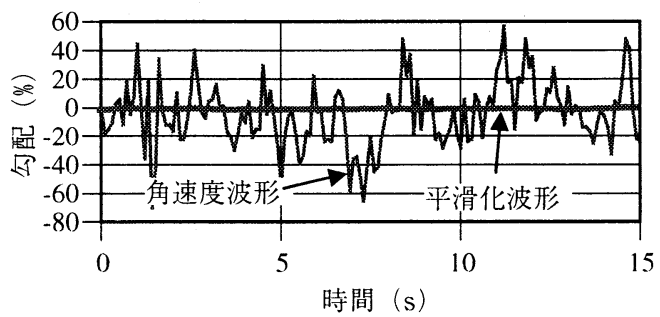

図－8スロープを登坂したときの角速度波形と平滑化波形

図－9 と図－10 に波打ち歩道（下り縦断勾配 9\%，登 り縦断勾配 11\%,下りから登りまでの横断勾配 8～10\%) を，比較的ゆっくり（時速 $8 \mathrm{~km} / \mathrm{h}$ 程度）で走行したと きの加速度の平滑化波形と平滑化した角速度（それぞ れピッチとロール）の積分波形である。縦断，横断と もに加速度センサにより推定した勾配は，実勾配に近 いものであった。

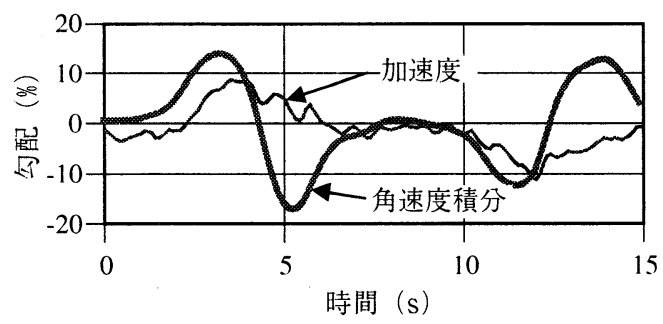

図 -9 勾配に換算した, 波打ち歩道を走行したときの加速度 と角速度積分值の平滑化波形（縦断勾配）

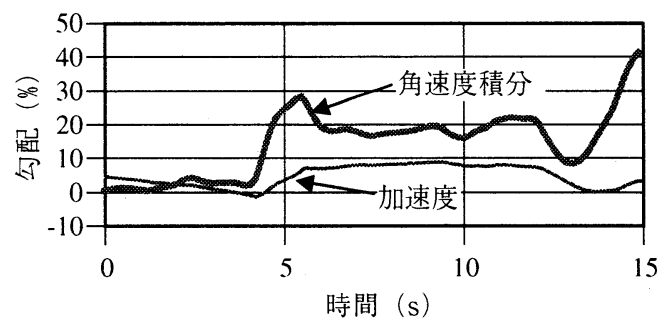

図－10 勾配に換算した, 波打ち歩道を走行したときの加速 度と角速度積分值の平滑化波形（横断勾配）

それに対し，角速度積分值では，勾配を検出した直 後（図－9では，5秒前後と 14 秒前後）にゴースト波 形が現れており，推定を混乱させている．横断勾配の 推定においても同様である。しかしながら，よりハイ スピードで走行した場合には, 加速度センサへの振動 の影響や，加速・減速時の影響を除去することが困難 になることも考えられ，ジャイロセンサの出力を信号 処理する工夫が望まれる。

\section{6. 調查例}

以上の手法を用いて，プローブ自転車により歩道， 自転車歩行者道の調查を行った。プローブ自転車に GPS（EMPEX 社製，ポケナビ map21ex）を装着し, 調 査ルートの緯度経度データを一旦 GPS のメモリ媒体に 記録した。その後，オフラインで各センサとの同期を とった. 各センサの出力は長さ 60 秒, 精度 12 ビット, 周波数 $500 \mathrm{~Hz}$ でサンプリングし，ノートブック型コン ピュータに取り込んだ。

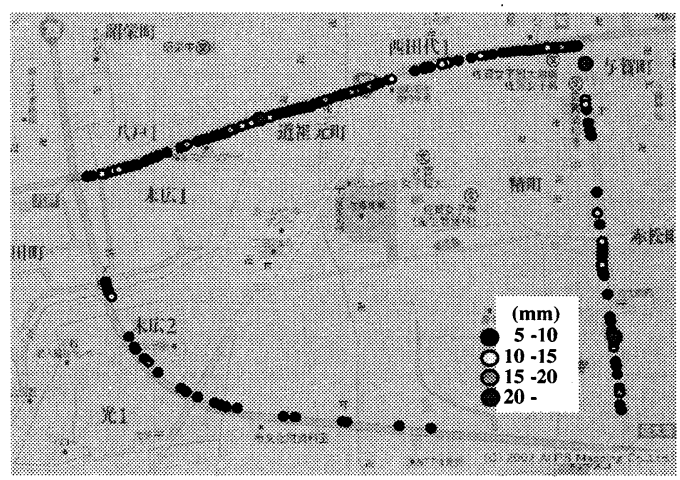

図ー11 プローブ自転車により計測した加速度から推定した 段差の分布

図 - 11 は段差の推定結果を GIS 上に重ね合わせた例 を示している，図に示す調査範囲は, 佐賀大学周辺道 路の歩道あるいは自転車歩行者道である. 段差, 幅員 ともに高さや幅毎に色分けし, 状態を可視化した。

このように，単純にセンサにより得られた時系列デ 一夕を地図上に重㸚わせることができるが，作業の 
簡便さや見やすさという点で, GIS 側の工夫が必要にな る.

\section{7. 考察}

歩道, 自転車歩行者道の整備状況に関する情報を, 走行しながら収集するプローブ自転車を開発した。プ ローブ自転車には, 磁気センサ, 加速度センサ, ポテ ンショメータ, ジャイロセンサを搭載し, 段差, 幅員, 勾配を計測，推定するシステムとした。

段差の高さ推定では，段差の境界形状が一定という 条件下で実用に耐えうる推定結果が得られた。しかし， 実際の歩道等には種々の形状の段差がみられ，これら 段差形状の違いを含めて推定するためには，モデルの 変数を増やす必要があるだろう。例えば, 振動加速度 波形の瞬時周波数情報を利用することが一つの方法で あると考えられる。また，実際の利用においては，あ る閥值を設定し，それ以上であれば歩行，車いす走行， 自転車走行に対するバリアとして表現する方法が簡便 で有効であると考えられる。

また，加速度センサの出力から段差高が推定できる だけでなく, 舗装の優劣, インターロッキングの目地 間隔などの情報を抽出することもできる ${ }^{5 !}$ ここような 路面の情報は, 詳細な物理的数值として表現するだけ でなく, 段差情報とともに，生の加速度デー夕を総合 的に評価することにより, 走行の快適性として表現す ることも有効である，逆に，振動に現れにくい情報， すなわち雨天時における滑りやすさ等も重要な情報で あり, 今後, 計測, 推定する手法の確立が必要になる だろう。

幅員の推定では, 誤差の絶対值は実幅員の大小に関 係なく，大きい場合で $0.2 \sim 0.4 \mathrm{~m}$ であった，そして， 幅員が小さいほど相対的に誤差が大きくなる傾向にあ った。本研究におけるこのような誤差は，スラローム 走衍技術に関するヒューマンエラーが大きな原因とし て考えられ，その意味に扔いて本手法は計測・推定手 法として必ずしも望ましくない，今後，計測手法の見 直しも視野に入れて, 精度向上を図る必要がある。し かし, 実用上, 精度は $0.1 \mathrm{~m}$ 単位でも十分すぎると考え られ，さらに公開のためのマップ表示を想定した場合， $0.5 \mathrm{~m}$ 単位程度に丸めた值でも十分であると考えられる。

勾配の推定では, 振動や直進加速度などの影響を受 ける加速度波形と角速度波形を，カルマンフィル夕に より平滑化し，ノイズを除去してトレンドを抽出した。 加速度波形に拈いては，DCに近い低周波成分が重力加 速度分に相当するという考えによった。トレンドから 推定した勾配は, 自転車の大きな加減速がない場合や, 上下動が少ない場合に有効であった。しかし，例えば， 歩道を横切る自動車用のすりつけ勾配が設けられるこ
とによってできる波打ち状の歩道では，その勾配の変 化が激しいため，プローブ自転車により計測する加速 度への影響が大きく，平滑化の効果が適切に発揮され ない場合もある。このような場合には，ジャイロセン サの情報を副次的に利用することが有効であると考え られる。本研究では, ジャイロセンサにより得られた 角速度から積分した角度データに, ドリフト様のゴー スト波形が認められており，今後，この問題の解決が 勾配推定精度向上の鍵になるといえる。

歩道を中心とした道路空間は，実態として管理が行 き届いていないだけに6), 高齢化の進展を見据えた歩道 等のバリアフリー化は喫緊の課題である。しかしなが ら, 歩車道境界に見られる段差, 景観を意識した種々 の舗装材, 車の出入りのための勾配, 幅員に関わるさ まざまな障害物等は，転倒などを誘発する，交通弱者 に重くのしかかるバリアであることを現実として社会 全体が実感しているとはいい難い。それは，社会の大 半が自動車依存で, 交通強者にまわっていることに本 質的な原因があると思われる。このような背景のもと， 交通弱者の視点で，持続可能なコンパクトなまちづく りの方向性を示唆することは, 土木計画学の使命であ るともいえる，プローブ自転車システムは，そのため の有効な一手段と考えられる。すなわち，プローブ自 転車を利用することで，より広範囲の多元的な情報を 短時間に収集することができ，それら情報を整理する ことで，見過ごされやすい，問題点を浮き彫りにする ことができる。

現段階では，プローブ自転車による調査の対象を歩 道，自転車歩行者道の段差，幅員および勾配に絞って いるが, 段差, 勾配は，その物理量がバリアの程度と 直結しやすいのに対し，幅員は性質が異なる。実際の 歩道上には, 電柱, 看板, 植栽等の存在だけでなく, 乗り上げ駐車, 放置駐輪, 歩行者, 自転車との錯綜が ある。そして，同一箇所においても，有効幅員が変動 するという側面を持ち合わせている。つまり，バリア の要素として幅員を見る場合, 幅員という構造的問題 以外に, 機能上の複合的な問題が潜在しており, それ らも常に視野に入れておく必要がある。そして, 前述 のように, 幅員計測の手法改善の余地もあるが, この ような, 複合的問題を抱える実態の情報を入手するた めには, 今後, 画像分析手法や超音波センサ計測法な どを検討する必要があるだろう。

現在, センサの出力は A/D コンバータを介してコン ピュータに直接記録しているが, 記録媒体の容量の都 合上, 長時間, 大容量デー夕の記録は困難である。し たがって, 実利用に際しては, 大容量のデータレコー ダの利用, あるいは, 携帯電話等の IT 機器を用いて, 直接サーバへデー夕を伝送する方法も検討課題となる。 さらに, GPS データのセンサ出力との完全同期化, デ 
ータベースの構築, GIS における可視化を自動的に行う

システム構築など, 今後の課題となる.

\section{謝辞}

本研究は, 平成 14 年度佐賀大学低平地研究プロジェ クトの助成および平成 15 年度ユニベール財団研究助成 による研究の一部である。関係各位に感謝いたします。

\section{参考文献}

1) 東京都生活文化局 消費生活部生活安全課商品安全 係: 高齢者の事故防止マニュアル, 2002.

2）斎藤健治, 清田 勝: 自転車利用の視点から見た持
続可能な共生社会における環境, 社会福祉・健康, 教育, Human Interface, 6(1), pp.1-8, 2004.

3) 斎藤健治, 井上伸一, 細谷 聡, 清田 勝: ハンド ルと車体のふれからみた高齢者の自転車操作の特 徵, 人間工学, Vol. 39-5, pp.241-249, 2003.

4) 斎藤健治, 井上伸一, 細谷 聡, 清田 勝: 自転車 歩行者道の勾配と段差が高齡者の自転車操作に及 ぼす影響, 人間工学, Vol. 41-1, pp.36-39, 2005.

5) 白川龍生, 川村 彰, 中島繁則, 中辻 隆: 車両の 振動加速度を利用した路面プロファイル推定シス テムについて, 交通工学, Vol. 38-6, pp.32-41, 2003.

6）津田美知子: 通行帯のデザイン, 技法堂出版, 東京, 2002.

\section{プローブ自転車による自転車歩行者道のバリア調査法}

斎藤健治**・清田 勝***

歩道，自転車歩行者道に扔けるバリアに関する情報を効率よく収集するためのプローブ自転車を開発し た.このプローブ自転車には, 磁気センサ, 加速度センサ, ポテンショメータ, 傾斜センサ, ジャイロセ ンサが搭載されており，段差の高さ，幅員，勾配を推定することができる．段差の推定については種々の 形状に対応すること, 幅員の推定についてはヒューマンエラーの介在を防止すること, 勾配の推定につい てはジャイロセンサの情報を有効利用することが課題となった。行政等における実利用のためには, 大容 量記憶媒体やリアルタイム処理方式の採用, GPS との同期, GIS 上でセンサ出力波形を変換して可視化す るシステムが必要となる.

\section{Investigation of Barrier on Bicycle-Pedestrian Track with Probe Bicycle*}

\section{By Kenji SAITOU** • Masaru KIYOTA***}

The purpose of this study was to develop probe bicycle that investigate and collect the information about the barrier on pedestrian track and bicycle-pedestrian track. The barriers such as difference-in-level, narrow width and slope were detected with accelerometers, potentiometer and gyroscope-sensors which were carried on the bicycle. The management of the difference-in-level with various shapes, the prevention of human error in the estimate of width, the effective use of the information from the gyroscope-sensors were needed for the practical use of probe bicycle. 